\title{
THE UNDERPRICING OF NASDAQ IPOS IN THE HEALTHCARE SECTOR FROM MARCH 2020 TO APRIL 2021
}

\author{
Raffaele Visconti \\ $\mathrm{PhD}$ and Subject expert in Corporate Finance at "Università degli studi di Napoli Federico II"- Naples - Italy - Via \\ Cintia n. 21
}

DOI: http://dx.doi.org/10.38193/IJRCMS.2021.3409

\begin{abstract}
The research analyzes the average level of underpricing for companies in the Healthcare sector, listed on the Nasdaq from March 2020 to the end of April 2021. The COVID19 pandemic, which has developed all over the world, has made it appropriate for many companies in the sector to be listed in stock markets for the collection of Equity to finance the development of vaccines, drugs and equipment, directly or indirectly linked to the expansion of the Pandemic. There is a very high underpricing, even comparing it with that relating to all sectors of the economy, in the same time interval. The introduction indicates the research hypotheses to be tested; the second paragraph examines the prevailing doctrine on the subject, highlighting the differences in the nonidentical time frames and in the different stock markets of reference. These studies concern in particular the US stock markets, but references of analysis are reported regarding Taiwan, China, Italy and the United Kingdom. The data downloaded from the Nasdaq website is then analyzed. The research hypotheses formulated in the initial part of the work are substantially confirmed. A comparison is made with the speculative bubble formed at the end of the 90 s, caused by the access to the market of many companies operating in the internet sector. An attempt to explain anomalies in the functioning of the market refers to behavioral finance and the difficulty of evaluating innovative sectors of the economy, or in any case sectors that are facing an extraordinary event.
\end{abstract}

KEYWORDS: Underpricing, IPO, IPOs Healthcare, Behavioral finance;

\section{INTRODUCTION}

A particularly interesting topic of corporate finance is represented by underpricing in IPOs. With this term we indicate the phenomenon for which there is, in many cases, a positive difference between the price recorded on the secondary market on the first day of listing and the placement price in the IPO phase. This value, indicated in percentage terms, represents the first day return. Analyzes conducted in relation to the stock markets of various countries and to different time contexts, highlight the existence of this phenomenon, albeit with a very variable intensity over time. This issue has been extensively covered by the scientific literature, both through theoretical analyzes and empirical research. In this research I propose to analyze the underpricing of the IPOs carried out from the 
beginning of March 2020 to the beginning of Avril 2021 on the Nasdaq, relating to companies operating in the Healthcare sector. The COVID19 pandemic has led many companies in the sector to go public and, consequently, to raise equity to finance, in many cases, investments directly or indirectly linked to the pandemic. The research aims to test the following hypotheses:

Hypothesis 1 - The average underpricing of the companies analyzed is much higher than the average market one.

Hypothesis 2 - The variability of the underpricing of individual companies in the Healthcare sector, measured by the Standard Deviation, is very large compared to other sectors

\section{LITERATURE REVIEW}

An authoritative doctrine [1] has highlighted, through empirical analyzes, the considerable variability of underpricing over time. It assumed, in the US stock markets, an average value of $7 \%$ in the 1980 s. Between 1990 and 1998 the value stood at 15\%. In the years 1999 and 2000, when many Internet companies were listed, this value reached $65 \%$. The considerable variability of the phenomenon under analysis is explained through theses that can be grouped into the following categories. The existence of information asymmetries between the various parties involved in the placement of the securities; the different risk class to which listed companies belong in a given period; the greater uncertainty associated with the valuation of companies operating in innovative sectors; to the excessive optimism of investors that would find an explanation in behavioral finance [2] (Ritter and Welch, 2002). Among the first scholars to analyze underpricing was Ibboston, (1975) [3] who found an average value of $11.40 \%$ for IPOs made on US markets during the 1960s. A subsequent research conducted by Ritter (1984) [4], concerning a sample of about 5,000 IPOs made in the USA between 1960 and 1982, showed an average underpricing of $18.80 \%$. With regard to information asymmetries, in the work of Rock (1986), [6] it is assumed that there are investors who have higher-level information about the quality of the company and its development prospects. In accepting the placement offer, a problem of adverse selection would arise for less informed investors. When the offer price turns out to be lower than the expected value of the shares, less informed investors will, in many cases, see their demand for securities go all-out. This occurs because the subjects better informed about the real economic and financial prospects of the company, will participate in the placement offer with substantial orders. Otherwise, less informed investors will, in all likelihood, obtain all the required securities, since investors with superior information will refrain from participating in the placement offer. Less informed investors, to protect themselves from this adverse selection problem, will be willing to buy the securities at a price lower than their expected value, thus leading to underpricing. The phenomenon in question would have the function of compensating underwriters who are less informed of the risk they are assuming. Along the same lines Beatty and Ritter (1986), [7] highlight, in their empirical analysis, a direct relationship between uncertainty about the value of the company and underpricing. A higher uncertainty about the value of a security corresponds to the request by investors for a higher 
expected return and, consequently, for a higher underpricing. In this analysis, the uncertainty about the "real" value of a stock, the age of the company, the sales of the last pre-IPO year and the size of the placement offer are used as proxies. In 1980 Baron and Holmstrom, [8] highlight the link that exists between the issuing company and the Investment Bank in charge of placing the securities. The Investment Bank would have every interest in establishing a lower share price to facilitate the placement of shares with final investors. There is obviously an opposite interest on the part of the issuing company, which is mainly interested in maximizing the sums collected in the IPO phase, for the same number of shares placed on the market. Information asymmetries generally lead to a solution of this type. The underwriters would be in possession of information on the potential demand for securities by the market that is not known by the issuing company. The top managers of the company would not have the opportunity to observe the real commitment of the Investment Bank in the execution of its business. These circumstances would lead to the issue of the new shares at a lower price than what would have occurred in the absence of information asymmetries and perfect observability of the investment bank's. Theoretical models based on the information asymmetries of the various subjects participating in the placement show, that there is a positive correlation between asymmetric information and underpricing.

This considerable variability of the phenomenon is explained, among other reasons, by the different composition of the risk class to which listed companies belong in a given period. Some scholars, such as Campbell et Al. 2001, [9] believe that the increase in underpricing is linked to greater uncertainty regarding the valuation of companies operating in innovative sectors. These companies generally have a clear prevalence of intangible assets, many of which, in the event of the company's financial failure, cannot be subject to an autonomous possibility of realization. The considerable variability of operating results and net financial results makes it difficult to forecast future cash flows. Ritter \& Welch, in 2002, explain how the excessive optimism of investors, in many circumstances, hardly determines an "appropriate" price for an IPO on the stock market.

A study, (Gao et Al., 2019) [10] concerning the Taiwan market for the years 2009 to 2011, highlights the difference between hi-tech companies and non-hi-tech companies for the purpose of examining underpricing. The authors emphasize that, in most of the studies concerning underpricing, this distinction is not made. It is interesting, considering the difference between the strategies of the issuing companies, motivations and long-term performance, between traditional economic sectors and innovative companies. The analysis by Li et Al., 2018 [11] is particularly interesting, who examined the IPOs carried out on the Chinese stock markets from 2004 to 2013, with the aim of testing whether there are differences between the issues prior to the 2008 crisis and the following ones. The analysis highlights how the underpricing of listed companies after the financial crisis is lower than that recorded in the bullish phase preceding the 2008 crisis. Other authors (Ellul \& Pagano, 2006) [12] have noted that after market liquidity and liquidity risk are important determinants of IPOs 
underpricing. Their study, involved 337 British IPOs effected between 1998 and 2000. It is considered as the investment sentiments of investors, both an important factor on which both the underpricing and the timing of the placement of the securities depend. To take advantage of the windows of opportunity generated by a high level of stock prices, many companies go public when investor sentiment is high. In many cases this period coincides with a phase of excessive market evaluation (Bellonia et Al., 2013) [13]. For the explanations that refer to behavioral finance, the analysis of Shiller in 2003 [14] and Hirshleifer in 2015 [15] should be highlighted. Cognitive errors such as Overconfidence, Mental Accounting and Disposition Effect, serve to explain how market prices are not always compatible with the information efficiency theory of financial markets (Fama, 1970) [16]. These theories, which were dominant in the academic world in the 1970s, have been questioned, at least in their more orthodox versions, trying to explain some market inefficiencies through Behavioral Finance.

There could be an excess of euphoria that would involve many investors in the bullish phases of the market which tends to accelerate the increase in prices. This implies that some economic agents would not act rationally, leading to the creation of speculative bubbles.

In this regard, some of the speculative bubbles formed in the second half of the 1900s are listed. They are: The Japanese stock price and land price bubble of the 1980s; The October 1987 stock crash and the Technology, Media and Telecom bubble of 1999 - 2000.

Underpricing represents an opportunity cost for the issuing company. The loss for the company that accesses the stock market, caused by having issued shares at a price lower than that of the first day of listing, is also called "money on the table".

In many cases this is the highest cost of the entire process that leads to the listing of a company. As an example, in a famous Corporate Finance Text (Brealey et Al., 2006), it is highlighted that the eBay company was listed in 1998, placing 3.5 million shares at a placement price of $\$ 18$ per share. On the first day of listing, the stock traded at $\$ 47.38$ per share. Underpricing was $163.22 \%$ and the total "left money on the table" was approximately $\$ 103$ million.

\section{3 - THE NASDAQ}

More than 3,000 companies are listed on the Nasdaq, in many cases with multiple share classes. The listing of securities of a different nature, both as regards the rights with an equity content and as regards the voting rights, can have different effects on the corporate control structures (Ecchia,...). Most of the listed companies belong to the technology sector, but the Healthcare sector has had a considerable presence on this market for many years. The name comes from an acronym - "National Association of Securities Dealer Automatic Quotation". The market was born in 1971 and was the first fully 
electronic stock exchange in the world. In a first phase, information on prices was disseminated online in order to disseminate them on an ongoing basis and to give greater transparency to the negotiations. The telematic transmission of orders took place in 1987. Daily exchanges are particularly high, second only to those of the NYSE (New York Stock Exchange). It should be noted that the same company that manages the market, The Nasdaq Stock Market Inc., is listed on the Nasdaq. The main index that summarizes the performance of this stock exchange is the Nasdaq Composite. This is a basket that includes most of the listed securities and is, consequently, highly representative of the entire market. Another important index is the Nasdaq100, which groups together the hundred most important nonfinancial companies, both American and foreign, listed on the Nasdaq. Among the most relevant companies in the list we have Microsoft, Facebook, Amazon and Apple. At the end of the 90s, stocks listed on this market, many of which were linked to the expected developments of the Internet, underwent a considerable increase (Fig. 1)

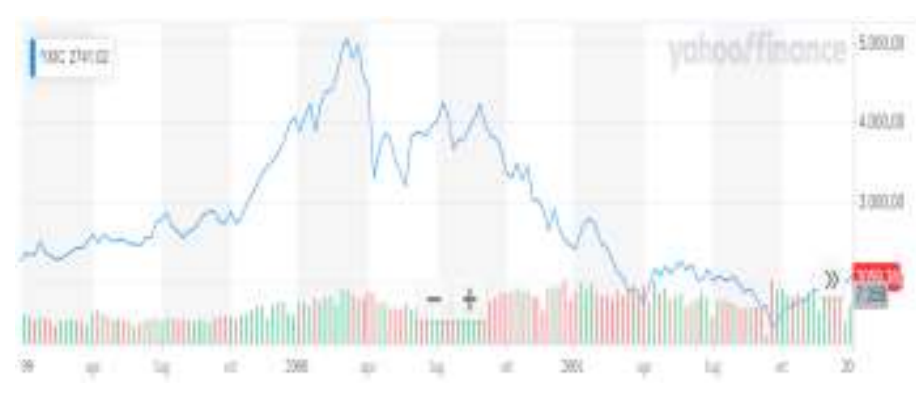

Fig. 1 - Nasdaq Composite Index Dot.com Boom

for which, in many cases, no justification could be found by resorting to fundamental stock market analysis. Traditional indicators such as price-earnings or other multiples such as the ratio between Price and cash flow, could not be applied to companies that for years had closed their financial statements at a loss and, in many cases, had negative equity. The expectations of the investors were based on the prospects of a significant development of the client base of these companies which, however, occurred in several cases. The prices of the services offered tended to decrease due to strong competition in the various sectors and led to a low level of profitability, even in the case of sales growth. Another reason for market instability was to be found in the lock-up clauses, for securities reserved for company employees, lasting 12,18 months and even longer. This circumstance did not make it possible to sell shares, when they would have served to keep market prices at more acceptable levels. The sales were concentrated in short periods of time, at the end of the term established in the contract for the placement of the securities. In the early months of 2000, sales began to increase and, in about a year and a half, the Nasdaq Composite Index, which had exceeded 5,000 points, fell below 2,000 points. Many listed companies went bankrupt, others continued their business, however, causing very high losses to the shareholders who had invested at the peak of the market. To explain the reasons 
that led to this speculative bubble, in my opinion, we need to resort to Behavioral Finance. Even some authoritative media, unwittingly, dealing with these dynamics daily in the Bull Market phase, led the bubble to feed itself.

\section{DATA SOURCE AND ANALYSIS}

The data for the realization of this research, relating to the initial yield of the individual issues and those at 30 days and six months, were taken from the Nasdaq website and reported on the Excel file.

The data relating to the number of listed companies and the capital collected in the IPO phase, were downloaded from the World Federation of Exchange website. The graphs relating to the performance of the Nasdaq Composite Index were found by Yahoo. Finance. We reviewed the 154 IPOs of the Healthcare sector, from the beginning of March 2020 to the beginning of April 2021. From data analysis (Table I)

Table I - Underpricing IPOs Healthcare

From march 2020 to avril 2021

\begin{tabular}{|c|c|c|c|}
\hline Mean & $\min$ & Max & DevSt \\
$32.91 \%$ & $-43.78 \%$ & $249.38 \%$ & $50.73 \%$ \\
\hline
\end{tabular}

an average underpricing of $32.91 \%$ emerges, with values ranging from $-43.78 \%$ to $+249.38 \%$. This wide variability of the data around the average value is quantified by a very high Standard Deviation, which is $50.73 \%$. I also looked at the average return at 30 days (Table II) and at six months (Table III).

TABLE II - AVERAGE YELD AT 30 DAY

\begin{tabular}{|c|c|c|c|}
\hline $\begin{array}{c}\text { Return } 30 \text { days } \\
\text { mean }\end{array}$ & $\min$ & Max & DevSt \\
\hline $35.71 \%$ & $-57.78 \%$ & $229.25 \%$ & $55.44 \%$ \\
\hline
\end{tabular}

The values of the First day return are, on average, substantially maintained in the three-month comparison, with a yield increase of $2.8 \%$.

TABLE III - AVERAGE RETURN AT SIX MONTHS

\begin{tabular}{|c|c|c|c|}
\hline $\begin{array}{c}\text { Return } 6 \text { month } \\
\text { mean }\end{array}$ & $\min$ & Max & DevSt \\
\hline $75.87 \%$ & $-76.22 \%$ & $631 \%$ & $116.79 \%$ \\
\hline
\end{tabular}

In the calculation of the average yield over six months, a value of $+75.87 \%$ is noted. Consequently, 
on average, even those who had bought the securities on the first trading day, despite having paid, on average, the shares, at a much higher price than the issue price, would find themselves with quite high potential capital gains.

The examination of the IPOs referring to all listed sectors concerns 627 listed companies. For 47 it was not possible to detect first day returns, so the study refers to 580 listed companies. There was an underpricing of $18.89 \%$ for the entire market, much lower than that shown for the Healthcare sector alone, which stood at $32.91 \%$. The same Standard Deviation, which indicates the dispersion of the data around their average value, albeit high (45.23\%), is still more contained than that calculated for the Healthcare sector $(50.73 \%)$

Table IV - Underpricing

Nasdaq "All sector"

march 2020 - Avril 2021

\begin{tabular}{|c|c|c|c|}
\hline Mean & min & Max & DevSt \\
\hline $18.89 \%$ & $-50.00 \%$ & $537.50 \%$ & $45.23 \%$ \\
\hline
\end{tabular}

The two research hypotheses formulated in the initial part are therefore substantially confirmed

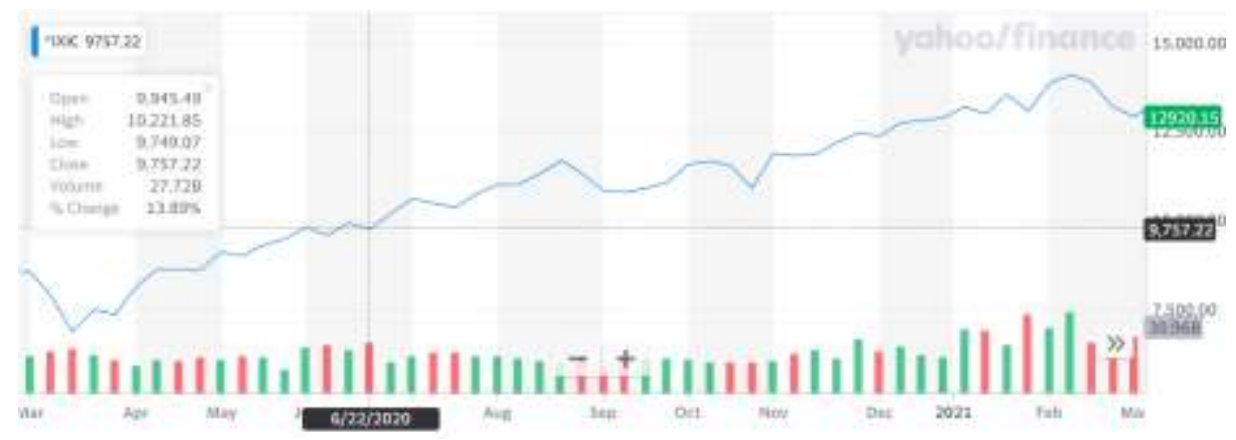

FIGURE 2 - NASDAQ COMPOSITE INDEX BULL MARKET 2020 - 2021 SOURCE: YAHOO FINANCE

Observing the trend of the NASDAQ Composite Index from March 2020 to April 2021, we note consistent and substantially uninterrupted growth in the years considered, without having significant retracements. 
International Journal of Research in Commerce and Management Studies

ISSN 2582-2292

Vol. 3, No. 04 July-Aug; 2021

Table V - New Listed Companies

\begin{tabular}{|c|c|}
\hline YEARS & Number of new Listed Companies \\
\hline 2010 & 83 \\
2011 & 73 \\
2012 & 75 \\
2013 & 116 \\
2014 & 176 \\
2015 & 565 \\
2016 & 69 \\
2017 & 89 \\
2018 & 150 \\
2019 & 135 \\
2020 & 184 \\
\hline
\end{tabular}

Source: Our Elaboration from Dataset WFE

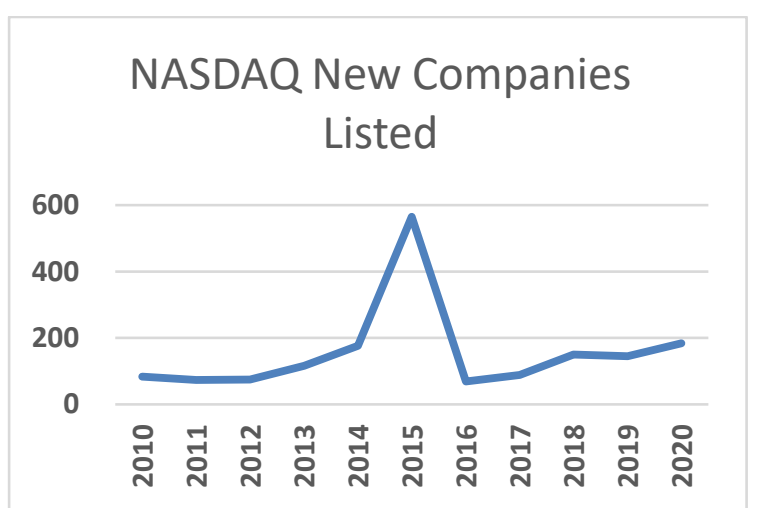

Figure 3 - New Company Listed 
Table 6 - Capital Raised Through the IPO

\begin{tabular}{|c|c|}
\hline YEARS & $\begin{array}{c}\text { Capital raised through the IPOs } \\
\text { \$ millions }\end{array}$ \\
\hline 2010 & 8.243 \\
2011 & 10.958 \\
2012 & 23.848 \\
2013 & 17.418 \\
2014 & 21.907 \\
2015 & 13.033 \\
2016 & 7.075 \\
2017 & 8.335 \\
2018 & 22.301 \\
2019 & 26.154 \\
2020 & 51.314 \\
\hline
\end{tabular}

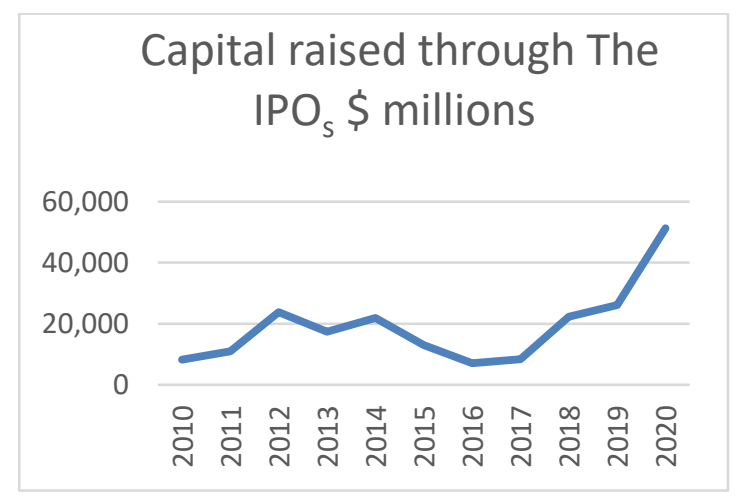

\section{3 - Capital raised through the IPOs.}

The Tables shows the data on the number of listed companies and the capital raised on the market (TableV e VI), for all economic sectors, from 2010 to 2020. It should be noted, for the year 2020, an increase of the companies that access the market and, mainly, of the capital raised through IPOs, which are the highest in the last 10 years. The Nasdaq has confirmed that it is the main market for raising equity, precisely by innovative companies or, in any case, companies in which both scientific and technological research activities are at very high levels.

\section{CONCLUSIONS}

The study carried out shows a very high average underpricing for companies belonging to the Healthcare sector admitted to the NASDAQ in the period from March 2020 to April 2021. The 
considerable dispersion of the data around the average value, measured by the standard deviation, was also it is particularly high. The research hypotheses formulated in the introductory part were therefore confirmed. The values were not considered only in absolute terms but compared with the data referring to all the companies listed on the NASDAQ in the same period, regardless of the sector they belong to. The reasons could, in my opinion, be sought in information asymmetries between issuing companies and final investors. Many of these companies are directly or indirectly linked to pharmaceutical research to counter the effects of the Pandemic caused by COVID19. In my opinion, a considerable weight is represented by the euphoria of many investors, willing to pay the newly issued securities at prices much higher than those recorded in the placement phase, thus determining a particularly large First day return. The explanations of these remarkable performances, even after the placement of the securities, can be found in behavioral finance. There is also an increase in the number of companies entering the NASDAQ in the last two years and an increase in capital raised on the market which, for the year 2020, has the highest amount in the last ten years. This market is confirmed as a very important financing channel through equity for technological and scientific innovation.

\section{REFERENCES}

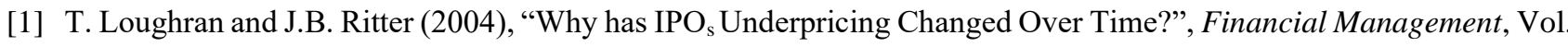
33 , n. 3, pp. 5 - 37

[2] J.B. Ritter and I. Welch, (2002), "A Review of IPO Activity, Pricing and Allocations", Yale School of Management, Working Paper

[3] R.G. Ibboston, (1975), "Price Performance of Common Stock New Issues", Journal of Financial Economics, Vol 2, Issue 3, pp. 235-272

[4] J.R. Ritter, (1984), "Signaling and The Valuation of Unseasoned New Issues: A comment", Journal of Finance, Vol. 39, n. 4, pp. $1231-1237$

[5] F. Dalle Vedove, G. Giudici \& P.A. Randone, (2005), "L'evoluzione delle offerte pubbliche iniziali in Italia", BitNotes di Borsa Italiana, n. 14

[6] K.F. Rock, (1986), "Why New Issues are Underpriced”, University of Illinois at Urbana

[7] R.P. Beatty and J.R. Ritter, (1986), "Investment banking, reputation and the Underpricing of Initial Public Offering", Journal of Financial Economics, n. 15, pp. 213 - 232

[8] D.P. Baron and B. Holmstrom, (1980), "The Investment Banking Contract for New Issues under Asymmetric Information: Delegation and the Incentive Problem”, The Journal of Finance, Vol. 35, n. 5, pp.1115 - 1138

[9] J.A. Campbell, M. Lettau, G.M Burton and X .Yexiao, (2001), "Have individual stock become more volatile? An empirical exploration of idiosyncratic risk", Journal of Finance, n. 56, pp. 1 - 43

[10] S. Gao, T. Chieh - TseHou, (2019), “An Empirical Examination of IPO $_{\text {s }}$ underpricing Between High-technology and non-Hit-Technology Firms in Taiwan”, Journal of Emerging Market Finance, Vol. 18, Issue 1, pp. 23 - 51

[11] R. Li, W. Liu, Y. Liu and Song-Bing Tsai,(2018), "IPO Underpricing After the 2008 Financial Crisis: A Study of the Chinese Stock Markets”, Sustainability, Vol. 10, Issue 8

[12] A. Ellul \& M. Pagano (2006), "IPO Underpricing and After Market Liquidity", Review of Financial Studies", Vol. 19 , pp. $381-420$

[13] A. Bellonia, T. Passaretti, (2013), "Seasonality in Equity Raising on Stock Markets. Windows of opportunity? Empirical Evidence from China, India, Brazil and South Africa”, Journal of Knowledge Management, Economics and Information Technology, Vol. III, Issue 3, 


\section{International Journal of Research in Commerce and Management Studies}

ISSN 2582-2292

Vol. 3, No. 04 July-Aug; 2021

[14] R. Shiller., "From Efficient Markets Theory to Behavioral Finance”, The Journal of Economic Perspectives, 2003, Vol. 17, n. 1, pp. 83-104

[15] D. Hirshleifer, (2015), “Behavioral Finance”, Annual Review of Financial Economics”, Vol. 7, n.1, pp. 133 - 159

[16] E. Fama, (1970), "Efficient Capital Markets: A Review of theory and Empirical Work”, Journal of Finance, Vol. 35, pp. $383-417$

[17] R. Brealey, S. Myers, F. Allen and S. Sandri, (2006), "Principi di Finanza Aziendale”, McGraw-Hill, pag. 364

[18] B. Ecchia, R. Visconti (2016), "The Extra Vote as Bonus for Loyalty Shares in the Evolution of the French Model. What Effects does it have On Shareholder Relationships, Long Termism and Company Market Value?", International

Journal of Business and Social Science, Vol. 7, n. 10, pp. 116 - 132 